\title{
Ecological determinants of health as presented in the report published by the Institute for European Environmental Policy
}

\author{
Marcin Pasek, Wojciech Sakłak
}

\author{
Wydział Turystyki i Rekreacji, Akademia Wychowania Fizycznego i Sportu w Gdańsku, Gdańsk \\ Address for correspondence: Marcin Pasek, Wydział Turystyki i Rekreacji, Akademia Wychowania Fizycznego \\ i Sportu w Gdańsku, 80-336 Gdańsk, ul. Kazimierza Górskiego 1, tel. 585547 125, marcin.pasek@awfis.gda.pl
}

\section{Abstract}

As defined by WHO, environmental health covers those health aspects of present and future generations that depend on the chemical, physical, biological and psychosocial factors of the environment. Effective action to improve the health of the society and its natural environment must take place mainly within the close collaboration of the health and environment ministries, but also within other non-governmental areas of activity. Regarding the concept of healthy population in a healthy environment, it is necessary to present the current situation in as much detail as possible, and to outline the possible directions of development.

The aim of the paper is to analyse the report titled 'The Health and Social Benefits of Nature and Biodiversity Protection' published by the Institute for European Environmental Policy.

With numerous references to the particular problems of integrating health and ecology, the report is the first of its kind on a continental scale. The conclusions it presents, related to numerous research studies, should provide a boost to their practical implementation.

In relation to the body of the report, the paper discusses the concept of environmental public health and provides a brief description of environmental health awareness of modern man. In the summary we flagged the need to draw attention to the problems that remain unaddressed in the report but that bind the environmental environment with human health.

Key words: anthropogenic environment, biodiversity, the environment, health

Słowa kluczowe: bioróżnorodność, środowisko antropogeniczne, środowisko naturalne, zurowie

\section{Introduction}

Health policy relating to environmental health determinants can be considered both on the institutional and individual level. The former includes numerous laws, regulations or directives regulating the relations between man and the environment. In this case, the focus is mainly on the actions aimed at protecting human health against environmental threats [1], though not forgetting the legal regulations governing recreation in a natural setting, which protects and sometimes even increases our health resources [2].

The other view is based on the assumption that each person is characterized by an individual cognitive rep- resentation of his or her health [3]. This knowledge can be rather procedural, a record of our habits created as a result of socialization, but there is also the possibility of verbalizing our own conscious concept of health [4]. With regard to environmental issues, this can be reflected in comprehending the purifying influence of nature on man [5] or the deliberate avoidance of those achievements of modern civilization that have dubious health benefits. Putting the knowledge to practice refers to the positive health effects that nature can have in regenerating our strength in a natural setting [6-9]. The psychological effects are primarily considered [10], but there are also reports of physiological effects [11], while the practice of functioning in a transformed environment re- 
fers to its effects on human health, both in the biological [12] and in the mental sphere [13, 14].

This complex reality necessitates the introduction of radical changes in public health thinking. Tim Lang and Geof Rayner [15] have taken on this task, proposing five major public health models, of which the environmental public health model, combining the material, biological and socio-cultural aspects of health, is particularly interesting. In times of dynamic environmental change, human relationships with ecosystems are becoming more and more significant, and so Lang and Rayner consider why modern public health has almost forgotten this elementary bond.

The first model they describe is a sanitation-environmental model in response to the theory that diseases such as the plague, smallpox or cholera are caused by bad air, water and food. The existence of risks posed through direct contact between people and indirect contact - via food, water or air - was also assumed. The main methods of fighting these threats included personal hygiene and improved working conditions.

The second is the biomedical model focusing on the individual or the entire society, as evidenced by the popularization of vaccination since the nineteenth century. In the middle of the twentieth century, the United States spent only $4.4 \%$ of GDP on health care, in 2009 $-17.4 \%$, and in 2040 it is likely to increase to around $29 \%$ [16]. Despite the growing expenditure and development of medical technologies, no solutions have been invented for non-communicable diseases, a good example of which are overweight and obesity plaguing the country. This justified the emergence of the third social-behavioural model - assuming that in the fight for health commercial methods such as social marketing or the theory of gentle suggestions should be followed, in order to influence social behaviour in just causes. Examples include the increase of donors of blood or bone marrow using influential ambassadors to encourage actions aimed at public good.

The fourth model has been defined by the authors as techno-economic, where the success of public health efforts is dependent on the progress of knowledge and economic growth. Both these factors - the development of the economy and knowledge - determine the rise in the standard of living, which in turn contributes to improving health.

Although these models deserve attention, due to their anthropocentric nature they marginalize the role of the natural environment in health care. A model that focuses on the biological and chemical conditioning of health addresses this deficit. To a certain extent, it is linked to the social-environmental model, more commonly known as the ecological model of Urie Bronfenbrenner [17], but it places special emphasis on social themes, at the same time decreasing the importance of the natural environment in reducing somatic symptoms. An advantage of an ecological public health model seems to be that it integrates the other models, shaping modern thinking about the complexity and dynamics of the man-environment system that is not confined to closed scientific fora, and so encouraging debate across wider society.
The promotion of activities to improve the environment and health among different social groups is one of the elements of the 'Environment and Health' Programme, established by the Council of Ministers on June 5, 2001, a joint project of the Ministry of Health, the Ministry of the Environment and the Committee for Scientific Research, scheduled to have been implemented in 2000-2003. It covered the whole country, but it was particularly important in ecologically-endangered areas. Its main purpose was annual evaluation and the possibility of modification. The programme was coordinated by the Minister of Health and managed by a representative of the Minister of Health and the Minister of the Environment - the Director of the Institute of Occupational Medicine and Environmental Health in Sosnowiec.

The 'Environment and Health' Programme was aimed at the creation of an effective system for addressing environmental health threats in line with the recommendations of the World Health Organization and EU guidelines. Achieving this goal was to be made possible by the realization of the following three projects: implementation of a system for recognizing and assessing health risks associated with exposure to environmental hazards; programming, implementing and evaluating the effectiveness of environmental and health actions; and finally developing and implementing modern prevention and ensuring specialist medical care in ecologically endangered areas.

As part of the 'Environment and Health' Programme, five surveys were conducted to explore the current knowledge and public opinion on environmental health threats [18]. The studies have shown that about $80 \%$ of adult Poles recognize the relationship between human health and the state of the natural environment. Of those who perceive this relationship, $85 \%$ believe that environmental pollution can have a significantly negative impact on health. It is interesting that the perception of the environmental threat is not related to the place of residence. It was shown that equally affected by the impact of pollution on human health was the resident of a degraded area and that living in an uncontaminated area, as well as town and country residents. The belief that individual actions can contribute to the improvement of the environment and so to human health was shown to be reinforced. Half of the respondents believed that Poland's accession to the European Union and the related tightening of legislation and economic growth were an opportunity to improve the environment. Comparing these results to those presented by the studies conducted in the 1980s and 1990s, it can be ascertained that the social awareness of the importance of the relationship between the environment and health has increased [19, 20].

Another important area of research was the assessment of generally available information on the state of the environment and the impact of pollution on human health. One in two respondents positively assessed the availability of this type of information, but more than a third considered that access to be limited. Nearly $10 \%$ of respondents believed that there was no access to such information at all. Research shows that the public expects 
competent information about environmental hazards. The Polish respondents quoted television programmes, press articles, radio programmes, educational films and different types of leaflets devoted to this subject as the most frequent sources of information on the state of the environment in relation to human health. Information bulletins, websites, and databases are used to a minimum extent, which is a testimony to the continuing lack of knowledge about the principles and access to information [18].

Given the rather unsatisfactory research results on the level of ecological and health consciousness, the European Commission's initiative towards fuller public awareness of this issue is more than welcome. The breakthrough report from the Secretariat of the Convention on Biological Diversity (CBD) and the World Health Organization sheds new light on the connection between biodiversity and health. The report presented at Green Week 2015 details the complex interaction between ecosystems and health in terms of the spread of infectious diseases such as SARS, West Nile fever, and Ebola virus, which cause millions of deaths each year. In addition, it warns of the risk of over-exposure of antibiotics to the variety of microorganisms, which is of particular importance in the treatment of infectious diseases. A diversity of microorganisms is essential not only to promote health within ecosystems, but also to support regulation of the functioning of the human immune system. Braulio Dias, Secretary General of the CBD Secretariat, urged practitioners to use the report's findings to "promote a more integrated policy combining environmental, agricultural and health sectors in the hope of increasing recognition of the role of biodiversity in supporting food security and human health" [21].

As a result of the study conclusions, a detailed report on the health and social benefits of nature and biodiversity protection [22] was published a year later by the Institute for European Environmental Policy. This body is a leading centre for the analysis and development of environmental policies in Europe, focusing on sustainable development and such environmental policy issues as agriculture, fisheries, transport, rural and regional development, climate change and industrial pollution.

\section{The Health and Social Benefits of Nature and Biodiversity Protection - report by the Institute for European Environmental Policy}

The first of the issues raised was air protection. The European Environment Agency [23] estimates that air pollution is the cause of hundreds of thousands of premature deaths in Europe. Some air pollutants have a significant effect on cardiovascular and respiratory systems, contributing to pulmonary dysfunctions, asthma or chronic bronchitis [24, 25]. The EU still lags behind the United States [26] and Japan [27] with regard to the maximum admissible levels of air pollution, at the same time being far from recognizing the WHO guidelines - more rigorous than those contained in EU legislation
[28]. The social and health effects of poor air quality are not equally problematic in every European country, the problem is most aggravated for the populations living in the Benelux, Northern Italy and Eastern Europe.

The results of empirical studies indicate that the role of nature in improving air quality is very complex. The benefits of using the potential of nature are vital because of the enormous costs of treating diseases of environmental origin. Its usefulness is mainly seen in the absorption of pollutants by plants, regulation of microclimate and emission of natural volatile organic compounds with fungicidal and bactericidal activity [29].

This effect can be used by planting trees near intersections of main roads, which may be more desirable from the point of view of spatial planning and investment costs than the enlargement of urban parks [30]. In the urban space more and more greenery is seen on the walls and roofs of buildings, undoubtedly strengthening the pleasing aesthetic experience, but in terms of air purification it is less effective than the bushes or trees growing nearby. For this reason, green walls and roofs should be a complement rather than an alternative to traditional vegetation. [31] In 2013, the Commission introduced national directives regarding the emission ceilings for pollutants [32]. Legislation on PM10 suspended particulate matter and nitrogen oxides $\left(\mathrm{NO}_{2}\right)$ in the form of Directive 2008/50/EC can contribute to meeting air quality targets, thereby reducing medication, hospitalization and lost working days, and consequently expenditure on public health.

The report also focuses on the improvement of microclimatic conditions. The immediate vicinity of green complexes provides both an elevated level of humidity and thermal comfort within the areas inhabited by urban, suburban and rural populations. In developed and densely populated cities the temperatures are much higher than in suburban areas. Climate change projections suggest an increase in average and extreme temperatures throughout Europe and the resulting public health consequences. A heat stroke is becoming a real risk, occurring when the cooling effect of perspiration is not sufficient and despite this defensive reaction the body becomes overheated [33].

In Europe, temperatures in urban centres may exceed by even $12^{\circ} \mathrm{C}$ the temperatures outside of cities [34]. A comparative study of Paris and the district of Marne de Val revealed [35] that consecutive high day and night temperatures were factors determining mortality among adults over 65 years of age. Children and adolescents can be even more sensitive to heat [36]. Excess heat is also an important element of occupational risk, especially for those working in the open, which leads to reduced productivity and economic consequences [37]. Studies have also shown that air quality deteriorates during heat [38]. The so-called heat islands in the urban environment are characterized by high levels of volatile organic compounds and street ozone, affecting the spread of dust [39].

Other studies [40] conclude that there will be 86,000 additional deaths per year in 2071-2100 in the EU-27 Member States compared to the EU-25 average for the 
period of 1961-1990, linking this to the increase in the temperature of the environment. Most of these deaths are expected in urban areas [41]. In view of this, emphasis is given to the role of the natural environment as a source of coolness in the shade and evapotranspiration [42], which effectively limit heat stress. Apart from vegetation, also reservoirs and watercourses can contribute to the reduction of the heat island effect and night air temperatures [43]. An example is the Lisbon City Park, covering a quarter of a hectare, where the temperatures on the hottest days were up to $6.9^{\circ} \mathrm{C}$ lower than the surrounding temperatures [44]. Also, long-term studies of three Göteborg parks show that the cooling effect can be observed even within $1 \mathrm{~km}$ of the park boundary [45]. In American cities, for example in Los Angeles, emergency services recommend urban parks as a kind of cooling centres, as effective as public air-conditioned rooms, assuming they can be cooler than the interiors of homes. The report also referred to the interesting Polish proposal to create an urban microclimate in the location of the Copernicus Science Centre in Warsaw - the green roof of the building situated on the banks of the Vistula is, on the one hand, a breeding area for ducks, and on the other, it provides effective thermal insulation in the summer. Roofs in Warsaw can heat up to $80^{\circ} \mathrm{C}$ while the biologically active surfaces preserve ambient temperature [46].

However, it should be noted that governmental responses to urban heat stress should go beyond the aspects of the architectural environment, and include the readiness of health care systems, work time management in extreme temperatures, and information campaigns on good practices in coping with heat stress [47].

Exposure to excessive noise is considered to be the second most important environmental cause of poor health, preceded by ultrafine particles of $\mathrm{PM}_{2,5}$ [48]. The noise present in urban areas and the natural environment is caused in particular by transport and industrial activity. The World Health Organization estimates that $40 \%$ of the population in EU countries is exposed to traffic noise at levels exceeding $55 \mathrm{~dB}, 20 \%$ are exposed to noise levels exceeding $65 \mathrm{~dB}$ during the day, and more than $30 \%$ to levels exceeding $55 \mathrm{~dB}$ at night. The most common effects include hearing loss [49], tinnitus, defined as hearing sound in the absence of its external source, and irritability observed among 20 million European adults, and sleep disorders, signalled by at least 8 million [50]. Problems with effective relaxation produce daytime sleepiness, decreased sense of well-being, and disrupted cardiovascular functions [51].

In the literature, the effects of noise exposure on the cardiovascular system have been reported to be an increase in catecholamines and cortisol secretions, and increased blood pressure, heart rate and cardiac output [52]. Long-term exposure to noise, particularly not subsiding at night, can lead to heart attacks and strokes, as confirmed by studies in the London Heathrow Airport population [25]. Other reports have confirmed additional health effects such as an increased risk of diabetes [53], significant increase in the purchase of sleep and anxiety medications [54], and cognitive impairment in children [55].
In 2011, the WHO estimated that at least one million years of healthy life is lost each year due to traffic noise [48]. In addition, the European Environment Agency (EEA) estimates that noise is responsible for at least 10,000 premature deaths and 43,000 hospitalizations in Europe each year [50].

Vegetation plays a decisive role in limiting the health implications of noise exposure. Sounds are redistributed through their reflection, diffraction and dispersion at the level of trunks, branches and leaves [56]. According to listening studies [57], where recordings of various types of traffic noise were combined with natural sounds such as fountain noise or birds singing, the addition of natural sounds reduced the reception of road traffic noise. Several other studies have shown the potential of natural sounds that accompany flowing water in reducing the nuisance of street noise [58]. In several European cities, these innovations are already being applied, complementing the silencing process thanks to the construction of acoustic screens.

Planting vegetation along the top edge of the noise barrier can also significantly improve the acoustic parameters of the obstacle at a short distance behind the screen [59]. A pedestrian or cyclist moving within one metre of the obstacle has a guaranteed noise reduction of $8-12 \mathrm{~dB}$. Also vegetation planted at the foot of the barrier softens the soil and increases the silencing effect at the surface [60].

Apart from air pollution, heat stress and noise, the report places great importance also on the positive relationship between human health and biodiversity. These have been presented in the following sections on the direct health benefits of experiencing nature, while physiological and psychological effects have been analyzed both in a contemplative model of spending time as well as the time spent doing various forms of physical activity in nature.

Public health effects related to functioning in green areas may take the form of increased levels of physical activity, and so reduce the risk of chronic diseases such as diabetes and cardiovascular disease, as well as an enhancement of the immune function [61]. However, there is uncertainty about the actual role of these areas as an element of preventive care, because causal relationships are difficult to grasp due to their multifaceted nature [62]. All the same, based on the information provided in the literature review, it is likely that valuable natural areas have a positive effect on the incidence of allergies and wellbeing [63], and can be considered as a basis for effective social and cognitive development in those children and adolescents who have difficulty concentrating and finding motivation to work [64]. Compared to classroom activities, the emotional and behavioural components are higher in younger age groups during classes performed in a forest setting [65]. These conclusions were supported by the finding [66] that children who spent the summer camp in nature were more friendly than those who spent it in the city. This urges that concrete action be taken regarding the urban planning of green areas, as the renewal of psychophysical strength after work and study is more 
effective in such conditions than in the case of resting in centres that lack these attributes [67].

Studies have also demonstrated the physiological reaction of the body to the environment: decreased blood pressure and pulse, decreased cortisol levels, suppression of sympathetic activity, and increased parasympathetic activity [68]. Many hospitals, centres for the elderly and sanatoria have been located in the vicinity of beautiful nature. In these cases, nature serves as a tool for therapeutic intervention, as confirmed by practical experience and positive patient feedback $[69,70]$.

Nature-related issues are also easily linked to physical activity that is closely identified with health. Increased physical activity within green areas is associated with a lower risk of stroke [71], cardiovascular disease [72, 73], and obesity [74]. Availability of such areas encourages people to exercise more frequently, including walking or cycling through green areas, which has the added benefit of reducing $\mathrm{CO}_{2}$ emissions by means of transport [75].

Also addressed was the problem of environmental stress caused by the removal or deterioration of the quality of natural habitats, and materialized in the form of chronic anxiety, chronic stress and high blood pressure [76], as well as the perception of health problems [77].

It is argued in extensive literature that physical activity in green areas has a particularly positive effect on mental health. Contact with nature helps to cope with stress and a more correct perception of one's health [78-80]. Evidence suggests that the proximity of green areas determining the attractiveness of the landscape, increases the level of physical activity of the population, and so they should be located in the immediate vicinity of residential areas. This effect is particularly noticeable when the green areas are situated no more than 1 kilometre from the house [81-84]. In Europe, there are several projects promoting active outdoor activities, for example in the Medvednica Nature Park in Zagreb, Croatia, or the Sintra-Cascais Natural Park, Portugal. There is still a large number of supporters of the recreational use of nature resources, with the popularity of mushroom and forest fruits picking, fishing and hunting being maintained.

A separate section of the report is devoted to social issues, their relationship with health issues being questionable, and certainly not as obvious as the issues discussed above. A broader review of this problem [85] indicates that staying in a natural setting allows for strengthening interaction and social position, a percentage reduction in crime and a decrease in aggression [86]. Similar importance is attributed to human interactions with the environment as part of volunteering work that builds a sense of spiritual unity with nature and a sense of rational management of the environment. These correlations were supported in the report by another example from the area of Poland - the development of tourist space for nordic walking amateurs in the Białowieża Forest, whose establishment and maintenance allows the professional involvement of the local rural community, promoting health through outdoor activity and increasing environmental awareness.

\section{Summary}

The problem of the human relationship with nature mentioned in the report should be of interest to the broadly understood health care. The more so because the results of research done thus far do not provide many examples of health care involvement in this issue, despite the undoubtedly important role of the natural environment in shaping health habits and reducing the incidence of chronic diseases due to more frequent contact with nature. Also in the field of rehabilitation, disability and mental health, nature can have a positive impact on the general well-being of people. The health sector has, therefore, not fully utilized the opportunity to improve the effectiveness of its activities, so far limited to the sphere of treatment rather than disease prevention.

Although the authors of the report realized an immense undertaking, both in terms of the content and geographical scale of the paper, its in-depth reading reveals that the issues discussed in some chapters were similar, if not the same, with regard to the problems addressed. The subsection 7.2 on the health benefits of physical activity in green areas and subsection 8.2 dealing with the health effects of living in an attractive natural location, may serve as an example.

However, with respect to the extent of research completed by the authors under the guidance of Patrick ten Brink, it is worth pointing out the need to generate interest in the many issues that remain unaddressed in the report, and that bind the human health and the state of the natural environment, for example the impact on human health of solar and ionizing radiation, water and air humidity, including both their positive and negative health effects, as well as soil and the presence of fertilizers and pesticides. In the light of the increasing threat of photochemical smog in large agglomerations, the importance of aerosanitary hazards in the context of physical activity should not be diminished. The problem overlapping the fields of physiology and ecology is also the health effects of staying in low pressure conditions at high altitudes. Relevant also remains the social and health impact of contact with the living elements of the ecosystem (poisonous reptiles, aculeata and ticks) and the dangers of ecological catastrophes (volcanic eruptions, tsunamis, earthquakes).

In the face of the above mentioned problems, the report titled 'The Health and Social Benefits of Nature and Biodiversity Protection' should be regarded as a vital document, commonly available through internet transmission, and so partly satisfying previously indicated needs in the field of environmental health education. Considering, however, the amendments that have been proposed to it, it should be treated as an important voice in social discussion, giving rise to a more detailed analysis of this issue in the future in order to gain the fullest possible knowledge of the links between health and ecology, and the best practical use of it. 


\section{References}

1. Siemiński M., Środowiskowe zagrożenia zdrowia, PWN, Warszawa 2001.

2. Zaręba D., Ekoturystyka, PWN, Warszawa 2000.

3. Sęk H., Subiektywne koncepcje zdrowia, świadomość zdrowotna a zachowania zdrowotne i promocja zdrowia, "Studia Minora Facultatis Philosophicae Universitatis Brunensis" 2000; 4: 17-34.

4. Puchalski K., Kryteria zdrowia w świadomości potocznej, "Promocja Zdrowia. Nauki Społeczne i Medycyna" 1994; 1-2: 53-69.

5. Krawczyk Z., Natura. Kultura. Sport. Kontrowersje teoretyczne w Polsce, PWN, Warszawa 1970.

6. Pańczyk W., Postugiwanie się ciałem wobec zagrożeń cywilizacji konsumpcyjnej, "Lider (numer specjalny)" 2003: 13-18.

7. Daniłowa N., Przyroda i nasze zdrowie, Wiedza Powszechna, Warszawa 1988.

8. Maller C., Townsend M., Pryor A., Brown P., St Leger L., Healthy nature healthy people: 'contact with nature' as an upstream health promotion intervention for populations, "Health Promotion International" 2005; 21 (1): 45-54.

9. Cox D.T., Shanahan D.F., Hudson H.L., Fuller R.A., Anderson K., Hancock S., Gaston K.J., Doses of nearby nature simultaneously associated with multiple health benefits, “Int. J. Environ. Res. Public Health” 2017; 14 (2), pii: E172.

10. Groenewegen P., van den Berg A., de Vries S., Verheij R. Vitamin G., Effects of green space on health, well-being, and social safety, "BMC Public Health" 2006; 6: 149.

11. Song C., Ikei H., Miyazaki Y., Physiological effects of nature therapy: A review of the research in Japan, "Int. J. Environ. Res. Public Health” 2016; 13 (8), pii: E781.

12. Briggs D., Environmental pollution and the global burden of disease, "Br. Med. Bull." 2003; 68: 1-24.

13. Pietrulewicz B., Zaleski Z., Deprywacja potrzeb, ocena wartości i decyzje w sytuacji zagrożenia ekologicznego, in: A. Biela (ed.), Stres psychiczny w sytuacji kryzysu ekologicznego, Towarzystwo Naukowe Katolickiego Uniwersytetu Lubelskiego, Lublin 1984.

14. Oudin A., Bråbäck L., Åström D.O., Strömgren M., Forsberg B., Association between neighbourhood air pollution concentrations and dispensed medication for psychiatric disorders in a large longitudinal cohort of Swedish children and adolescents, "BMJ open" 2016; 6 (6): p.e010004.

15. Lang T., Rayner G., Ecological public health: The $21^{\text {st }}$ century's big idea? An essay by Tim Lang Geof Rayner, "BMJ" 2012; 345: e5466.

16. Badora K., Ekologiczne zdrowie publiczne - model na miare XXI wieku, "Zeszyty Naukowe. Zdrowie Publiczne i Zarządzanie” 2012; 10 (1): 45-50.

17. Bronfenbrenner U., Ecological Models of Human Development, in: International Encyclopedia of Education, 3 ed. Elsevier, Oxford 1994.

18. Jarosz W., Brol J., Jarzębska B., Nowińska Z., Przewoźnik P., Postawa proekologiczna wyrazem troski o środowisko $i$ własne zdrowie, http://www.ietu.katowice.pl/wpr/Dokumenty/Konferencje/Szczecin/postawa_proekologiczna_ streszczenie.pdf (accessed: 22.12.2014P).
19. Gliński P., Świadomość ekologiczna społeczeństwa polskiego - dotychczasowe wyniki badań, "Kultura i Społeczeństwo" 1988; 3: 189-190.

20. Mirowski W., Świadomość ekologiczna współczesnego spoleczeństwa polskiego, in: W. Miowski, P. Gliński (ed.), Świadomość ekologiczna i spoleczne ruchy "Zielonych w Polsce”, Wydawnictwo IFiS PAN, Warszawa 1999.

21. https://ec.europa.eu/environment/efe/themes/green-week/ nature-health-centre-tomorrow_pl (accessed: 24.07.2015).

22. Brink P., Mutafoglu K., Schweitzer J-P., Kettunen M., Twigger-Ross C., Baker J., Kuipers Y., Emonts M., Tyrväinen L., Hujala T., Ojala A., The Health and Social Benefits of Nature and Biodiversity Protection. A Report for the European Commission (ENV.B.3/ETU/2014/0039), Institute for European Environmental Policy, London-Brussels 2016, https://www.slu.se/globalassets/ew/org/centrb/cnv/naturvagledning/ekosystemtjanster/ieep_2016_health_social_ benefits_ecosystemservices_biodiversity.pdf (accessed: 01.06.2017).

23. European Environment Agency, EEA Air Quality in Europe - 2015 Report, Copenhagen 2015.

24. Amann M., Bertok I., Cofala J., Gyarfas F., Heyes C., Klimont Z., Schöpp W., Winiwarter W., Baseline Scenarios for the Clean Air for Europe (CAFE) Programme, International Institute for Applied Systems Analysis (IIASA), Laxenburg (Austria) 2005.

25. Hansell A., Ghosh R.E., Blangiardo M., Perkins C., Vienneau D., Goffe K., Briggs D., Gulliver J., Historic air pollution exposure and long-term mortality risks in England and Wales: Prospective longitudinal cohort study, "Thorax" 2016; 71 (4): 330-338.

26. EPA, National Ambient Air Quality Standards (NAAQS), http://www.epa.gov/air/criteria.html (accessed: 28.04.2015).

27. Ministry of the Environment, Environmental Quality Standards in Japan - Air Quality, https://www.env.go.jp/en/air/ aq/aq.html (accessed: 28.04.2015).

28. WHO, Fact Sheet $N^{\circ} 313$ : Ambient (outdoor) Air Quality and Health, http://www.who.int/mediacentre/factsheets/ fs313/en/ (accessed: 28.04.2015).

29. Pugh T.A., MacKenzie A.R., Whyatt J.D., Hewitt C.N., Effectiveness of green infrastructure for improvement of air quality in urban street canyons, "Environ. Sci. Technol." 2012; 46 (14): 7692-7699.

30. Mitchell R., Maher B., Evaluation and application of biomagnetic monitoring of traffic-derived particulate pollution, "Atmospheric Environment" 2009, 43 (13): 2095 2103.

31. Currie B., Bass B., Estimates of air pollution mitigation with green plants and green roofs using the UFORE model, "Urban Ecosyst." 2008; 11: 409-422.

32. COM 919, Directive on the Limitation of Emissions of Certain Pollutants into the Air from Medium Combustion Plants, European Commission, Brussels 2013.

33. Kovats R., Climate change and human health in Europe, "BMJ" 1999; 318: 1682-1685.

34. Depietri Y., Renaud F.G., Kallis G., Heat waves and floods in urban areas: Policy-oriented review of ecosystem services, "Sustainable Science" 2011; 7: 95-107.

35. Laaidi K., Zeghnoun A., Dousset B., Bretin P., Vandentorren S., Giraudet E., Beaudeau P., The impact of heat islands 
on mortality in Paris during the August 2003 heat wave, "Environ. Health Perspect." 2012; 120 (2): 254-259.

36. Glasper A., Planning for a heat wave: the implication for health care, "British Journal of Nursing" 2011; 20 (13): 834-835.

37. Kovats R.S., Akthar R., Climate, climate change and human health in Asian cities, "Environment and Urbanization" 2008; 20 (1): 165-176.

38. Harlan S.L., Ruddell D.M., Climate change and health in cities: impacts of heat and air pollution and potential cobenefits from mitigation and adaptation, "Current Opinion in Environmental Sustainability" 2011; 3: 126-134.

39. Forest Research Report 2010, Benefits of green infrastructure, Forest Research, Farnham, http://www.forestry.gov.uk/ pdf/urgp_benefits_of_green_infrastructure.pdf/\$FILE/urgp benefits_of green_infrastructure.pdf (accessed: 01.06.2017).

40. EEA Report No 12/2012, Climate Change, Impacts and Vulnerability in Europe, European Environment Agency, Copenhagen 2012.

41. Secretariat of the Convention on Biological Diversity and the World Health Organization Connecting Global Priorities, Biodiversity and Human Health, Montreal, Quebec, Canada 2015.

42. Ennos R. Quantifying the cooling benefits of urban trees, in: Forestry Commission (2012). Trees, People, and the Built Environment, Proceedings of the Urban Trees Research, Forestry Commission, Bristol 2012.

43. Hathway E.A., Sharples S. The interaction of rivers and urban form in mitigating the urban heat island effect: a UK case study, "Building and Environment" 2012; 58: 14-22.

44. Oliveira S., Andrade H., Vaz T., The cooling effect of green spaces as a contribution to the mitigation of urban heat: A case study in Lisbon, "Building and the Environment" 2011; 46 (11): 2186-2194.

45. Upmanis H., Eliasson I., Lindqvist S., The influence of green areas on nocturnal temperatures in a high latitude city (Göteborg, Sweden), "International Journal of Climatology" 1998; 18 (6): 681-700.

46. Jurkiewicz J., The secret garden, http://www.kopernik. org.pl/en/exhibitions/ogrod-na-dachu/rosliny/ (accessed: 26.05.2015).

47. Huang C., Barnett A.G., Xu Z., Chu C., Wang X., Turner L.R., Tong S., Managing the health effects of temperature in response to climate change: Challenges ahead, "Environ. Health Perspect." 2013; 121 (4): 415-419.

48. WHO, Burden of disease from environmental noise, quantification of healthy life years lost in Europe, http://www. who.int/entity/quantifying_ehimpacts/publications/e94888. pdf (accessed: 17.02.2016).

49. Basner M., Babisch W., Davis A., Brink M., Clark C., Janssen S., Stansfeld S., Auditory and non-auditory effects of noise on health, "The Lancet" 2014; 383: 1325-1332.

50. EEA, Noise in Europe 2014, http://www.eea.europa.eu/publications/noise-in-europe-2014 (accessed: 04.2015).

51. Elmenhorst E.M., Elmenhorst D., Wenzel J., Quehl J., Mueller U., Maass H., Vejvoda M., Basner M., Effects of nocturnal aircraft noise on cognitive performance in the following morning: dose-response relationships in laboratory and field, "Int. Arch. Occup. Environ. Health" 2010; 83 (7): 743-751.
52. Münzel T., Gori T., Babisch W., Basner M., Cardiovascular effects of environmental noise exposure, "European Heart Journal" 2014; 35: 829-836.

53. Sorensen M., Anderssen Z.J., Nordsborg R.B., Becker T., Tjonneland A., Overvad K., Raaschou-Nielsen O., Longterm exposure to road traffic noise and incident diabetes: A cohort study, "Environmental Health Perspectives" 2013; 121: 217-222.

54. Bocquier A., Cortaredona S., Boutin C., David A., Bigot A., Sciortino V., Nauleau S., Gaudart J., Giorgi R., Verger P., Is exposure to night-time traffic noise a risk factor for purchase of anxiolytic-hypnotic medication? A cohort study, "European Journal of Public Health" 2013; 24: 298-303.

55. Hygge S., Noise and cognition in children, in: J.O. Nriagu (ed.), Encyclopaedia of Environmental Health, Elsevier, Burlington 2011: 146-151.

56. Van Renterghem T., Forssén J., Attenborough K., Philippe J., Defrance J., Hornikx M., Kang J., Using natural means to reduce surface transport noise during propagation outdoors, "Applied Acoustics" 2015; 92: 86-101.

57. De Coensel B., Vanwetswinkel S., Botteldooren D., Effects of natural sounds on the perception of road traffic noise, "Journal of the Acoustical Society of America" 2011; 129: $148-153$.

58. Galbrun L., Ali T., Acoustical and perceptual assessment of water sounds and their use over road traffic noise, "Journal of the Acoustical Society of America" 2013; 133: 227-237.

59. Forssén J., Hornikx M., Van Der Aa B., Nilsson M., Rådsten-Ekman M., Defrance J. et al., Toolbox from the EC FP7 HOSANNA project for the reduction of road and rail traffic noise in the outdoor environment, in: Proceedings of the Transport Research Arena 2014, Paris 14-17 April 2014.

60. Danish Road Institute, Noise barrier design: Danish and some European examples, Copenhagen 2010, http://www. ucprc.ucdavis.edu/pdf/UCPRC-RP-2010-04.pdf (accessed: 01.06.2017).

61. Hanski I., von Hertzen L., Fyhrquist N., Koskinen K., Torppa K., Laatikainen T., Karisola P., Auvinen P., Paulin L., Vartiainen E., Kosunen T.U., Alenius H., Haahtela T., Environmental biodiversity, human microbiota, and allergy are interrelated, "Proceedings of the National Academy of Sciences of the United States of America" 2012; 109 (21): 8334-8339.

62. Morris N., Health, well-being and open space: Literature review, OPEN space, Edinburgh 2003, http://www.openspace. eca.ed.ac.uk/pdf/healthwellbeing.pdf (accessed: 17.02.2016).

63. Kelz C., Evans G.W., Röderer K. The restorative effects of redesigning the schoolyard: A multi-methodological quasiexperimental study in rural Austrian middle schools, "Environment and Behavior" 2013; 12 (1): 1-21.

64. Laaksoharju T., Rappe E., Kaivola E., Garden affordances for social learning, play, and for building nature-child relationship, "Urban Forestry and Urban Greening" 2012; 11: 195-203.

65. Roe J., Aspinall P., The restorative outcomes of forest school and conventional school in young people with good and poor behavior, "Urban Forestry \& Urban Greening" 2011; 10: 205-212.

66. Collado S., Staats H., Corraliza J.A., Experiencing nature in children's summer camps: Affective, cognitive and behav- 
ioural consequences, "Journal of Environmental Psychology" 2013; 33: 37-44.

67. Tyrväinen L., Ojala A., Korpela K., Lanki T., Tsunetsugu Y., Kagawa T., The influence of urban green environments on stress relief measures: A field experiment, "Journal of Environmental Psychology" 2014; 38 (6): 1-9.

68. Horiuchi M., Endo J., Akatsuka S., Uno T., Hasegawa T., Seko Y., Influence of forest walking on blood pressure, Profile of Mood States, and stress markers from the viewpoint of aging, "Journal of Aging \& Gerontology" 2013; 1: 9-17.

69. Adevi A.A., Martensson F., Stress rehabilitation through garden therapy: The garden as a place in the recovery form stress, "Urban Forestry and Urban Greening" 2013; 12 (2): 230-237.

70. Pálsdóttir A.M., The Role of Nature in Rehabilitation for Individuals with Stress-related Mental Disorders: Alnarp Rehabilitation Garden as Supportive Environment, Doctoral thesis, Swedish University of Agricultural Sciences, Alnarp 2014.

71. Wannamethee S.G., Shaper A.G., Physical activity and the prevention of stroke, "Journal of Cardiovascular Risk" 1999; 6: 213-216.

72. Lee J., Scott D., Floyd M.F., Structural inequalities in outdoor recreation, "Journal of Leisure Research" 2001; 33: 427-449.

73. Sesso H.D., Paffenbarger R.S., Ha T., Lee I.M., Physical activity and cardiovascular disease risk in middle-aged and older women, "American Journal of Epidemiology" 1999; 150 (4): 408-416.

74. Nielsen T.S., Hansen K.B., Do green areas affect health? Results from a Danish survey on the use of green areas and health indicators, "Health and Place" 2007; 13: 839-850.

75. Moffat A.J., Pediaditi K., Doick K.J., Monitoring and evaluation practice for brownfield regeneration to greenspace initiatives. A meta-evaluation of assessment and monitoring tools, "Landscape and Urban Planning" 2010; 97 (1): 22-36.

76. Henwood K., Issues in Health Development: Environment and Health: Is there a Role for Environmental and Countryside Agencies in Promoting Benefits to Health?, Health Development Agency, London 2002.
77. Qureshi S., Kazmi S.J.H., Breutse J.H., Ecological disturbances due to high cutback in the green infrastructure of Karachi: Analysis of public perception about associated health problems, "Urban Forestry \& Urban Greening" 2010; 9 (3): 187-198.

78. Hartig T., Mitchell R., de Vries S., Frumkin H., Nature and Health, "Annual Reviews of Public Health" 2014; 35: 207-228.

79. Keniger L.E., Gaston K.J., Irvine K.N., Fuller R.A. What are the Benefits of Interacting with Nature?, "International Journal of Environmental Research and Public Health" 2013; 10: 913-935.

80. Thompson Coon J., Boddy K., Stein K., Whear R., Barton J., Depledge M.H., Does participating in physical activity in outdoor natural environments have a greater effect on physical and mental wellbeing than physical activity indoors? A systematic review, "Environmental Science \& Technology” 2011; 45 (5): 1761-1772 .

81. Neuvonen M., Sievänen T., Tönnes S., Koskela T., Access to green areas and the frequency of visits - A case study in Helsinki, "Urban Forestry \& Urban Greening" 2007; 6 (4): 235-247.

82. McMorris O., Villeneuve P.J., Su J., Jerrett M., Urban greenness and physical activity in a national survey of $\mathrm{Ca}$ nadians, "Environmental Research" 2015; 137: 94-100.

83. Giles-Corti B., Broomhall M.H., Knuiman M., Collins C., Douglas K., Ng K., Lange A., Donovan R.J., Increasing walking: how important is distance to, attractiveness, and size of public open space?, “American Journal of Preventive Medicine" 2005; 28: 169-176.

84. Roemmich J.N., Epstein L.H., Raja S., Yin L., Robinson J., Winiewicz D., Association of access to parks and recreational facilities with the physical activity of young children, "Preventive Medicine" 2006; 43 (6): 437-441.

85. Keniger L.E., Gaston K.J., Irvine K.N., Fuller R.A., What are the benefits of interacting with nature?, "International Journal of Environmental Research and Public Health" 2013; 10: 913-935.

86. Kuo F.E., Sullivan W.C., Aggression and violence in the inner city: Impacts of environment via mental fatigue, "Environment and Behavior" 2001; 33: 543-571. 